\title{
REPERCUSSÕES JURÍDICAS DA DOENÇA PREEXISTENTE NO CONTRATO DE SEGURO DE VIDA
}

\author{
Michael Cesar Silva ${ }^{1}$
}

\begin{abstract}
Resumo
O presente estudo visa a analisar as conseqüências jurídicas relacionadas com a ocorrência da doença preexistente no contrato de seguro de vida, a partir da interpretação do referido contrato, realizada sob o enfoque do princípio da boa-fé objetiva, da transparência e do direito à informação, delineados no ordenamento jurídico brasileiro, através do Código de Defesa do Consumidor (1990) e do Código Civil (2002). O princípio da boa-fé objetiva, elemento essencial do contrato de seguro, passa a relativizar a autonomia privada nas relações jurídicas contratuais, para permitir aos contratantes exercer sua liberdade contratual de forma equilibrada e cooperativa, em consonância com os princípios fundamentais presentes no Estado Democrático de Direito.
\end{abstract}

Palavras-chave: contratos, seguro de vida, boa-fé objetiva, princípios, informação.

\section{INTRODUÇÃO}

Com o crescente desenvolvimento econômico, ligado intimamente ao incremento da técnica e industrialização no século XX, o contrato de seguro ampliou sua área de atuação progressivamente, abrangendo outras modalidades de seguros. Desse modo, para prevenir o homem das situações de risco inerentes às atividades desempenhadas, deu-se a transferência do risco para o segurador, com a finalidade de resguardar o desenvolvimento das atividades econômicas e isentar o segurado dos prejuízos inerentes ao risco.

O presente estudo propõe proceder a uma releitura do contrato de seguro de vida, à luz do princípio da boa-fé objetiva, no intuito de contribuir, diante da questão relacionada à presença da doença preexistente no referido contrato, para que os contratantes possam exercer sua liberdade contratual de forma equilibrada e cooperativa, em consonância com os preceitos fundamentais erigidos no Estado Democrático de Direito.

1 Doutorando e Mestre em Direito Privado pela Pontifícia Universidade Católica de Minas Gerais. Especialista em Direito de Empresa pelo Instituto de Educação Continuada (IEC) da Pontifícia Universidade Católica de Minas Gerais. Graduação em Direito pela Pontifícia Universidade Católica de Minas Gerais. Possui experiência profissional na docência junto a Pós-graduação lato sensu (especialização) da Fundação Getulio Vargas - FGV DIREITO RIO, a Pós-graduação do Instituto Nacional de Medicina Legal de Portugal, I.P., a Pós-graduação lato sensu (nível especialização) do Departamento de Odontologia da Pontifícia Universidade Católica de Minas Gerais (Campus Coração Eucarístico), a Faculdade Mineira de Direito da Pontifícia Universidade Católica de Minas Gerais (Campus Coração Eucarístico e São Gabriel), ao Centro Universitário Newton Paiva e a Faculdade de Direito Promove. Participação em projetos e atividades acadêmicas relacionadas a realização e/ou coordenação de seminários, mini-cursos, palestras, orientação de pesquisa e de monografia de final de curso. Editor de Revista Jurídica. Membro de Conselho Editoral. Membro da Associação Mineira de Direito e Economia (AMDE). Advogado. Experiência profissional e atuação nas seguintes áreas: Direito Empresarial, Direito Civil, Direito do Consumidor e Direito Securitário.

Revista da Faculdade Mineira de Direito, v.12, n. 23, jan./jun. 2011 - ISSN 1808-9429. 
A pesquisa pautar-se-á na análise do problema, que envolve a estipulação do conteúdo do contrato de seguro de vida pelas partes, e sua correlação com a doença preexistente, em face dos parâmetros delineados pela boa-fé objetiva, no Código Civil de 2002 e no Código de Defesa do Consumidor.

Destaca-se que o princípio da boa-fé objetiva, por ser elemento essencial e imprescindível ao contrato de seguro (artigo $765 \mathrm{CC} / 02$ ), possui indubitável relevo na interpretação do modelo jurídico, desde a fase pré-contratual (tratativas), durante sua execução, e mesmo na fase pós-contratual (post pactum finitum).

Nesta esteira, o princípio da transparência e o dever de informação atribuído, aos contratantes (segurado e segurador) no momento de formação do contrato de seguro de vida, bem como durante toda a execução do contrato, em consonância com os preceitos norteadores da boa-fé objetiva, apresentam-se como fundamentais, no intuito de garantir contratações que assegurem a justiça contratual através da consagração da igualdade material entre as partes.

Merece destaque também a aplicação do Código de Defesa do Consumidor ao contrato de seguro de vida, por tratar-se indubitavelmente de uma relação de consumo, conforme consagrado no artigo $3^{\circ}$, $\S 2^{\circ} \mathrm{CDC}$ e reafirmado no julgamento da ADI $n^{\circ} 2.591-1 / \mathrm{DF}$ pelo Supremo Tribunal Federal.

\section{PRINCÍPIO DA BOA-FÉ-OBJETIVA}

\subsection{Lineamentos no ordenamento jurídico pátrio}

O princípio da boa-fé objetiva apresenta-se, na contemporaneidade, como um dos mais importantes princípios do Direito Privado, notadamente, no Direito Contratual, sendo, consagrado no ordenamento jurídico brasileiro, através de sua positivação no Código de Defesa do Consumidor (Lei 8078/90) e no Código Civil de 2002 (Lei 10.406/02).

O princípio em comento gerou profundas transformações no Direito Contratual, causadas pela relativização da autonomia privada dos contratantes, a qual passa a ser mitigada pela observância a novos deveres (anexos) inseridos na relação jurídica, que dele afluem na forma de obrigação secundária, bem como pela prevalência de funções intrínsecas ao mesmo, que visam a nortear a conduta (comportamento) dos contratantes ao adimplemento contratual.

A boa-fé objetiva foi inserida, inicialmente, no Direito Brasileiro, através da previsão legal do artigo 131, I, do Código Comercial de 1850, onde já se previa expressamente a boafé, de cunho contratual no tocante ao aspecto interpretativo. Todavia, a mesma relegou-se a letra morta da lei, sem maiores repercussões. Na égide do Código Civil de 1916, não havia 
previsão legal expressa sobre o referido princípio, pois, o diploma legal, bem como todo o ordenamento jurídico brasileiro, encontrava-se norteado pela boa-fé subjetiva, que denotava uma acepção psicológica, estado de ignorância do agente.

O princípio da boa-fé objetiva foi previsto de forma efetiva no ordenamento jurídico brasileiro, através de sua inserção no Código de Defesa do Consumidor, no artigo $4^{\circ}$, III (referencial interpretativo) e no artigo 51, IV (cláusula geral).

Posteriormente, o Código Civil de 2002, através da previsão legal dos artigos 113 (referencial interpretativo), 187 (vedação ao abuso de direito) e 422 (cláusula geral), trouxe a lume novo regramento do modelo jurídico no Direito Brasileiro.

Insta destacar que a boa-fé objetiva é, em verdade, um reflexo do princípio constitucional da solidariedade, consagrado no art. $3^{\circ}$, I, da Constituição da República, que se irradia através do Direito Obrigacional para todo o Direito Privado (TEPEDINO, 2003-2004).

O princípio da boa-fé objetiva representa um "modelo de conduta social, arquétipo ou standard jurídico" (MARTINS-COSTA, 2000, p.411), que se fundamenta na necessidade das partes atuarem reciprocamente com cooperação, lealdade, honestidade e confiança, no intuito de concretizar a diretriz da eticidade, preconizada no Código Civil de 2002.

Trata-se de uma regra de conduta, de comportamento ético, social, imposta às partes, pautada nos ideais de honestidade, retidão e lealdade, no intuito de não frustrar a legítima confiança, expectativa da outra parte, tendo ainda, a finalidade de estabelecer o equilíbrio nas relações jurídicas (ROSENVALD, 2005, p.80; FARIAS; ROSENVALD, 2006, p.40) ${ }^{2}$

O referido princípio ensejou a modificação da concepção tradicional de contrato como relação jurídica estática, que passa a ser visto como relação jurídica complexa e dinâmica (COUTO E SILVA, 1976, p.10-11) ${ }^{3}$, formado por um feixe de obrigações múltiplas e recíprocas, delineadas pela inserção dos deveres anexos, nas relações jurídicas obrigacionais.

Nesse sentido, a boa-fé objetiva, passa a integrar o negócio jurídico por meio dos chamados deveres anexos de conduta (proteção, cooperação e informação, dentre outros), os quais visam a consagrar sua finalidade precípua, qual seja o adimplemento do contrato, devendo ser observados na fase pré-contratual, de execução do contrato e pós-contratual. ${ }^{4}$

2 Nesse mesmo sentido, ver: CORDEIRO (2005, p.405); CORDEIRO (2007, p.632); FIUZA (2006, p. 410-411); LÔBO (2002, p.193); MARQUES (2006, p.216); NEGREIROS (2006, p.122-123); NORONHA (1994, p.152); NORONHA (2007, p.446-447); NOVAIS (2001, p.22-23); THEODORO JÚNIOR (2008, p.25-26).

3 Nesse sentido, ver: MARTINS-COSTA (2000, p.382-409); NORONHA (2007, p.75); MARQUES (2006, p.217-218); FARIAS; ROSENVALD (2006, p.47.

4 Giselda Maria Fernandes Novaes Hironaka preleciona que "[...] a boa-fé deve se consagrar nas negociações que antecedem a conclusão do negócio, na sua execução, na produção continuada de seus efeitos, na sua conclusão e na sua interpretação. Deve prolongar-se até mesmo para depois de concluído o negócio contratual, se necessário.” (HIRONAKA, 2003, p.113). Nesse mesmo sentido ver: TARTUCE (2007, p.220-221).

Revista da Faculdade Mineira de Direito, v.12, n. 23, jan./jun. 2011 - ISSN 1808-9429. 
Destaca-se, ainda, no tocante ao estudo do princípio da boa-fé objetiva, seu aspecto tridimensional exteriorizado pelas funções interpretativa, integrativa e de controle, as quais norteiam sua aplicação nas relações obrigacionais e, por conseguinte, nas contratuais. ${ }^{5}$

Destarte, a boa-fé objetiva visa ao adimplemento contratual e à limitação do exercício dos direitos subjetivos, notadamente, o abuso de direito, e nesse contexto, a autonomia privada passa a ser relativizada (SCHIER, 2006, p.46), ou seja, modelada, integrada, valorizada, ou mesmo para alguns, mitigada pela inserção da boa-fé objetiva nas relações contratuais.

O princípio da boa-fé objetiva impõe-se, assim, como elemento transformador de todo o Direito Obrigacional, irradiando-se para os demais ramos do Direito, e em especial, o Contratual (MARTINS-COSTA, 2002, p.611), donde se verifica sua importância nas relações jurídicas, evidenciando sua inegável força normativa no ordenamento jurídico contemporâneo.

\subsection{O delineamento das funções do princípio da boa-fé objetiva}

A boa-fé objetiva possui caráter tridimensional (MARTINS-COSTA, 2002, p.640; TEPEDINO; SCHREIBER, 2005, p.222; NORONHA, 1994, p.151), que se exterioriza através de três funções elencadas no Código Civil de 2002. Destas, a mais importante é a integrativa, pois a boa-fé integra qualquer relação obrigacional, e, por conseguinte, contratual.

Destarte, as funções visam a permear a aplicação da boa-fé objetiva, por todo o Direito Obrigacional, na busca do adimplemento contratual, e da limitação do exercício do direito subjetivo, permitindo assim o equilíbrio contratual almejado pelo ordenamento jurídico.

A função interpretativa (artigo 113 do Código Civil) preconiza a forma como o intérprete irá nortear-se para buscar o sentido adequado (correto) de examinar o conteúdo contratual pautado na observância da boa-fé objetiva nas relações jurídicas contratuais.

O referido princípio apresenta-se como cânone interpretativo, como referencial hermenêutico a nortear a interpretação dos negócios jurídicos, pautado na diretriz da eticidade. Trata-se de uma norma cogente, a qual não pode ser afastada pela vontade das

\footnotetext{
5 Nelson Rosenvald, em síntese acerca do princípio da boa-fé objetiva, explicita que “[...] a boa-fé objetiva é horizontal, concerne às relações internas dos contratantes. Atende ao princípio da eticidade, pois polariza e atrai a relação obrigacional ao adimplemento, deferindo aos parceiros a possibilidade de recuperar a liberdade que cederam ao início da relação obrigacional. Mediante a emanação de deveres laterais - anexos, instrumentais ou de conduta -, de cooperação, informação e proteção, os parceiros estabelecem um cenário de colaboração desde a fase pré-negocial até a etapa pós-negocial, como implicitamente decorre da atenta leitura do art. 422 do Código Civil. Dentro de sua tridimensionalidade (funções interpretativa, integrativa e corretiva), a boa-fé ainda exerce uma função de controle, modelando a autonomia privada, evitando o exercício excessivo de direitos subjetivos e potestativos, pela via do abuso do direito [art. 187, CC]. (ROSENVALD, 2007, p.89).
} 
partes, pois é dever jurídico imposto aos contratantes, que deverão comporta-se, obrigatoriamente, nos negócios jurídicos conforme os ditames da boa-fé objetiva.

A função interpretativa impõe que o intérprete, ao analisar as relações jurídicas obrigacionais, não se aterá a uma interpretação literal do negócio jurídico, mas, precipuamente, deverá pautar-se por uma interpretação, fundada na observância do sentido pertinente às convenções sociais inerentes àquela dada comunidade política. ${ }^{6}$

O intérprete buscará analisar as circunstâncias do caso concreto e a finalidade econômico-social do contrato (NEGREIROS, 2006, p.136), as quais desencadearam a manifestação de vontade dos contratantes, para através de esforço hermenêutico, determinar a solução adequada ao caso, dentro, evidentemente, dos contornos estabelecidos pela boa-fé objetiva, visando a não frustrar a legítima expectativa da outra parte.

A função de controle da boa-fé objetiva (artigo 187 do Código Civil) impõe limites ao exercício abusivo do direito subjetivo dos contratantes, para determinar até onde o mesmo é legítimo ou não, e desta forma obter o merecimento do ordenamento jurídico.

Assim sendo, a boa-fé objetiva "significa a aceitação da interferência de elementos externos na intimidade da relação obrigacional, com poder limitador da autonomia contratual, pois através dela pode ser regulada a extensão e o exercício do direito subjetivo." (AGUIAR JÚNIOR, 1995, p.24). Nesse sentido, a função de controle implica a limitação de direitos subjetivos dos contratantes (MARTINS-COSTA, 2000, p.382-409), os quais devem, necessariamente, observar os preceitos estabelecidos pela boa-fé objetiva no entabulamento dos negócios jurídicos, no intuito de que o contrato possa cumprir sua função social.

A boa-fé objetiva caracteriza-se, assim, como "máxima de conduta ético-jurídica" (FARIAS; ROSENVALD, 2006, p.44), que visa a coibir o abuso de direito subjetivo, qualificado no ordenamento jurídico, como ato ilícito, conforme artigo 187 do Código Civil, de modo a garantir o adimplemento contratual, segundo os preceitos norteadores do princípio.

Destarte, busca-se evitar o abuso de direito, reduzindo a liberdade de atuação dos contratantes, pois, determinados comportamentos, ainda que lícitos, não observam a eticidade preconizada pelo princípio da boa-fé objetiva, e assim, negligenciam os ditames da lealdade,

\footnotetext{
6 Nesse contexto, tem-se a prevalência da teoria da confiança, a qual se apresenta como um ecletismo da teoria da declaração (prevalência do texto em detrimento do aspecto psíquico) e da teoria da vontade (predominância da vontade interna das partes sobre a declaração), pela qual o intérprete buscará a vontade objetiva do contrato (vontade aparente do negócio jurídico), pautado nos ideais orientadores da boa-fé objetiva (ROSENVALD, 2005, p.89; FARIAS; ROSENVALD, 2006, p.43). Nesse sentido, posiciona-se doutrina abalisada sobre o tema. MARQUES (2006, p.212); AMARAL (2006, p.415); TARTUCE (2007, p.145); SETTE (2003, p.127128).
}

Revista da Faculdade Mineira de Direito, v.12, n. 23, jan./jun. 2011 - ISSN 1808-9429. 
honestidade e confiança mútua, que devem nortear a conduta das partes nas relações jurídicas, ferindo assim a legítima expectativa da outra parte.

A função integrativa da boa-fé objetiva (artigo 422 do Código Civil) é fonte criadora de novos deveres especiais de conduta a serem observados durante o vínculo obrigacional (NORONHA, 1994, p.157). São os chamados deveres anexos (instrumentais ou colaterais) de conduta, que passam a ser observados em toda e qualquer relação jurídica obrigacional.

É através da função integrativa que se irradiam os chamados deveres anexos de conduta, os quais afluem para todo o Direito Obrigacional, e, por conseguinte, para os demais ramos do Direito. Nesse contexto, o contrato passa a ser entendido como relação jurídica complexa e dinâmica, compreendido pela obrigação principal acrescida dos deveres anexos da boa-fé objetiva, que devem ser observados pelas partes, modificando-se, assim, o vínculo obrigacional estático outrora existente, restrito ao campo da prestação.

Trata-se da função mais importante do princípio da boa-fé objetiva, pois os referidos deveres que se originam deste passam, obrigatoriamente, a integrar qualquer relação obrigacional, como obrigação secundária ${ }^{7}$, para que essa seja equilibrada, e permita não frustrar a confiança mútua e a legítima expectativa dos contratantes.

Portanto, o Direito Obrigacional, e em especial, o Contratual, irão nortear-se pela autonomia privada acrescida pelos deveres anexos de conduta da boa-fé objetiva, no intuito de garantir o efetivo adimplemento da relação jurídica.

\subsection{Os deveres anexos de conduta da boa-fé objetiva}

A partir do princípio da boa-fé objetiva exsurgem os deveres anexos de conduta (laterais, instrumentais, colaterais), os quais se introjetam em toda relação jurídica obrigacional, no intuito de instrumentalizar o correto cumprimento da obrigação principal e a satisfação dos interesses envolvidos no contrato. ${ }^{8}$

Destarte, além do dever da prestação (obrigação principal) surgem, também, outros deveres de conduta durante a relação jurídica (obrigação secundária), os quais devem ser observados pelos contratantes, sob pena de quebra, de ofensa a boa-fé objetiva. (COUTO E SILVA, 1976, p.29-30; MARTINS-COSTA, 2002, p.634; LÔBO, 2005, p.76).

\footnotetext{
7 Nesse sentido ver: NEGREIROS (2006, p.150); MARQUES (2006, p.220); GOMES (2004, p.162).

8 Claudia Lima Marques preleciona que "Estes deveres de conduta que acompanham as relações contratuais vão ser denominados de deveres anexos (Nebenpflichten), deveres que nasceram da observação da jurisprudência alemã ao visualizar que o contrato, por ser fonte imanente de conflitos de interesses, deveria ser guiado e, mais ainda, guiar a atuação dos contraentes conforme o princípio da boa-fé nas relações. (MARQUES, 2006, p.219).
}

Revista da Faculdade Mineira de Direito, v.12, n. 23, jan./jun. 2011 - ISSN 1808-9429. 
Os deveres anexos podem ser compreendidos como deveres positivos e negativos, os quais através da sua inserção na relação jurídica, por meio da boa-fé objetiva, relativizam a autonomia privada, ao estabelecer deveres de comportamento, os quais nortearão a conduta das partes, nas fases pré-contratual, contratual e pós-contratual. (MELLO, 2001, p.316). ${ }^{9}$

Devido à importância concretizada pelos deveres anexos de conduta nas relações jurídicas obrigacionais, a doutrina firmou entendimento no sentido de que, quando se descumpre os deveres anexos de conduta, surge a chamada violação positiva do contrato ou adimplemento ruim (GARCIA, 2007, p.120; MARQUES, 2006, p.220; SILVA, 2002, p.82105; CORDEIRO, 2007, p.594-602; NALIN, 2006, p.226), pois a obrigação principal é cumprida, porém, tem-se o descumprimento dos deveres anexos (obrigação secundária). ${ }^{10}$

Desta forma, é imprescindível que as partes atuem nas relações jurídicas obrigacionais firmadas, com observância aos deveres anexos de conduta, os quais impõem para além da obrigação jurídica principal, deveres fiduciários (obrigação complexa e dinâmica), os quais objetivam resguardar a legítima expectativa e a confiança mútua existente entre as partes.

Por fim, assevera-se que a boa-fé objetiva materializa-se através dos deveres anexos de proteção (ou cuidado), cooperação (ou lealdade) e de informar (ou informação), dentre outros, pois sua enumeração não pode ser considerada taxativa. ${ }^{11}$

\subsubsection{O dever de informação}

O dever de informação impõe aos contratantes, o dever precípuo de informação acerca de todas as circunstâncias relevantes sobre o contrato, para que as partes possam, livremente, exercitar sua autonomia privada. Tem-se como o mais importante dos deveres anexos, pois a informação é fundamental para que os contratantes possam ser alertados sobre fatos de que não poderiam perceber por sua própria diligencia ordinária. (ROSENVALD, 2005, p. 109).

O referido dever tem por finalidade ampliar o conhecimento da informação disponibilizada aos contratantes na avença (FABIAN, 2002, p.157), pois a vontade de contratar deve ser esclarecida, informada, desde a fase pré-contratual até a fase pós-contratual, para permitir contratações em consonância com preceitos estabelecidos pela boa-fé objetiva.

9 Nesse sentido ver: BIERWAGEN (2003, p.56); HIRONAKA (2003, p.113); MARQUES (2006, p.218).

10 Flávio Tartuce expõe que "[...] Segundo o Enunciado n. 24 do Conselho da Justiça Federal, da I Jornada de Direito Civil, a quebra desses deveres anexos é modalidade de inadimplemento obrigacional, cuja responsabilidade independe de culpa. Para alguns autores, essa quebra da boa-fé objetiva conduziria a uma terceira modalidade de inadimplemento, ao lado da mora e do inadimplemento absoluto, denominada violação positiva do contrato." (TARTUCE, 2007, p.200 e 213, grifos no original).

11 Para maiores informações acerca dos deveres anexos da boa-fé objetiva ver: CORDEIRO (2007, p.586-631); MARTINS-COSTA (2000, p.437-454); FARIAS; ROSENVALD (2006, p.49-52); NORONHA (2007, p.7787).

Revista da Faculdade Mineira de Direito, v.12, n. 23, jan.jun. 2011 - ISSN 1808-9429. 
Destarte, o dever de informação "atuante na fase das tratativas, garante o exercício da liberdade contratual em condições aperfeiçoadas de autonomia, na medida em que o negócio será ou não concluído com base em uma melhor e mais completa apreensão da realidade." (NEGREIROS, 2006, p.112).

O dever de informação é extremamente valorado na sociedade contemporânea, em decorrência da cláusula geral de boa-fé objetiva, pois a informação acerca do conteúdo contratual é primordial e necessária aos contratantes, sendo assim entendido o dever de informação como obrigação secundária ao contrato e importante mecanismo de reequilíbrio contratual nas relações de consumo (MARQUES, 2006, p.772).

Evidentemente, o dever de informação encontra-se diretamente relacionado ao princípio da transparência, pois, as informações prestadas devem possuir destaque e clareza em seu conteúdo, para que os contratantes possam ter conhecimento prévio e efetivo de todas as obrigações assumidas no vínculo contratual.

No âmbito das relações de consumo, o direito à informação (artigo $6^{\circ}$, III CDC), estabelece a obrigatoriedade da informação, dentre os Direitos Básicos do Consumidor, o qual constitui dever fundamental do fornecedor em prestar informações claras e adequadas (transparentes) ao consumidor, relacionadas aos produtos/serviços fornecidos. (FABIAN, 2002, p.81-82). Nesse sentido, o direito à informação apresenta caráter dúplice, pois importa no dever de informar do fornecedor e no direito de ser informado do consumidor, pois a informação adequada sobre o conteúdo do contrato é essencial, no sentido de buscar o reequilíbrio da relação contratual.

Destaca-se, ainda, que parte doutrina firmou o entendimento de que, no âmbito da proteção do consumidor, o dever de informação valoriza-se, de modo a ultrapassar a fronteira dos deveres anexos de conduta da boa-fé objetiva, passando a integrar o próprio contrato, sendo considerado elemento essencial, ou seja, elemento integrante da obrigação principal (ROSENVALD, 2005, p.110; FARIAS; ROSENVALD, 2006, p.56-57; LÔBO, 2001).

\subsection{O corolário da boa-fé objetiva: transparência}

O princípio da transparência esculpido no artigo $4^{\circ}$ caput do Código de Defesa do Consumidor é um dos princípios norteadores dos contratos de consumo. Preconiza a maneira como a informação deve ser prestada ao consumidor durante a contratação, a qual deve ser clara, ostensiva, precisa e correta, visando a sanar quaisquer dúvidas no ato da contratação e garantir o equilíbrio contratual entre as partes contratantes. 
É um dos instrumentos, ao lado do dever anexo de informação, aptos a proteger a liberdade de escolha do consumidor, com vistas à consagração da boa-fé objetiva e justiça contratual na relação jurídica contratual.

Alguns doutrinadores entendem que a transparência advém do princípio da boa-fé objetiva, ou mesmo que se trata de um reflexo ou sub-princípio (RIBEIRO, 2003. p.146; SCHIER, 2006, p.49; NALIN, 2006, p.146 e 150; BENJAMIN; MARQUES; BESSA, 2007, p.57), que em consonância com o dever de informação, possui o intuito de qualificar $a$ informação prestada. Para outros, a transparência é corolário da boa-fé objetiva, possuindo papel fundamental nas relações jurídicas contratuais (GARCIA, 2007, p.30).

A transparência impõe a efetiva qualificação da informação sobre aspectos relevantes da avença, ligados, principalmente, a estipulação do conteúdo contratual, sob pena de haver violação do referido princípio, e em conseqüência, descumprimento da boa-fé objetiva. ${ }^{12}$

Isto porque, a transparência afeta a essência do contrato, pois a informação fornecida integra o conteúdo contratual, de modo a concretizar o reequilíbrio obrigacional do contrato, com vistas à consecução da igualdade material. Deste modo, a transparência apresenta-se como imprescindível instrumento de tutela das relações jurídicas contratuais.

Entretanto, em inúmeros contratos de consumo, e notadamente, no contrato de seguro de vida, verificam-se cláusulas contratuais, que impedem a compreensão adequada do segurado em relação aos termos do contrato, por não prestarem informações suficientes $e$ adequadas, ou mesmo por não serem transparentes, trazendo inúmeros prejuízos ao aderente.

Nesse contexto, o sentido adequado à transparência seria de qualificar a autonomia privada $^{13}$, através da efetiva liberdade de decisão do contratante, garantida pelo fornecimento de informações suficientes, adequadas e necessárias (transparentes) a realização da avença, as quais devem ser fornecidas desde o momento da formação do contrato.

O princípio da transparência em consonância com o dever de informação impõe ao fornecedor a obrigação de prover informação efetiva, descrição rigorosa e ostensiva do serviço prestado ao consumidor, sobretudo, naqueles casos em que, pela natureza da prestação ou pelo modo de contratar, encontra-se ínsita a presença do risco na relação contratual, ao qual é acrescida ainda a falta de informação ou mesmo o desconhecimento do contratante sobre aspectos relevantes acerca da contratação.

12 Nesse sentido ver: FABIAN (2002, p.68-70); MARQUES (2006, p.715); RIBEIRO (2003, p.136-137 e 146); TOMASETTI JUNIOR (1992, p.53); TARTUCE (2007, p.141-148);

13 Nesse mesmo sentido ver: NALIN (2006, p.147).

Revista da Faculdade Mineira de Direito, v.12, n. 23, jan./jun. 2011 - ISSN 1808-9429. 
Assim, a transparência e o dever de informação recaem sobre todas as cláusulas contratuais, as quais elencam direitos e deveres das partes, e permitem deste modo, o exercício da autonomia privada, conforme os preceitos erigidos pela boa-fé objetiva.

Portanto, a boa-fé objetiva, como manifestação da tutela da confiança, é concretizado através da transparência nas relações negociais, vinculando a parte que possui vantagens informativas, através da imposição do dever jurídico de informação clara, precisa e ostensiva de todo o conteúdo contratual, sem subterfúgios ou possibilidades de interpretações dúbias, no intuito de impedir que se frustrem as expectativas legítimas da contraparte, evidentemente, vulnerável no tocante às informações relacionadas ao teor das cláusulas contratuais da avença.

\section{CONTRATO DE SEGURO}

A necessidade de segurança é intrínseca ao ser humano. Desde a antiguidade o homem busca formas de proteção para resguardar-se de acontecimentos fortuitos. Com o desenvolvimento econômico, surge a idéia de buscar proteção econômica, donde exsurge incipidamente a noção de seguro. (GUERREIRO, 2004, p.1-3; MARTINS, 2005, p.5-8; MATOS; MOLINA, 2006, p.24; SHIH, 2003, p.3-4).

O contrato de seguro é o negócio jurídico que, na contemporaneidade, teve ampliado sua área de atuação, devido ao grande desenvolvimento econômico e tecnológico, que se empreendeu no século $\mathrm{XX}$, o que contribuiu para que inúmeros e novos tipos de seguros surgissem, para resguardar o patrimônio ou pessoa daquele interessado, em se proteger dos infortúnios (riscos) incidentes sobre diversos ramos da atividade econômica.

É o meio pelo qual a pessoa física ou jurídica protege-se contra os riscos, que porventura incidam sobre a vida ou o objeto de suas atividades. Desta forma, para preveni-lo de diversas situações de risco inerentes ao desenvolvimento de certas atividades perigosas, deu-se a transferência do risco para o segurador, visando a eliminá-lo dos meios de produção e condições de trabalho, de maneira a garantir o equilíbrio econômico nas atividades humanas, prevenindo, assim, o segurado dos prejuízos advindos do risco, contra os quais se garantiu através da contratação do seguro (BARROSO, 2007).

O contrato foi definido pelo artigo 757 do Código Civil, que explicita, em seu escopo, a diretriz norteadora do instituto, qual seja, a que "Pelo contrato se seguro, o segurador se 
obriga, mediante o pagamento do prêmio, a garantir interesse legítimo do segurado, relativo a pessoa ou a coisa, contra riscos predeterminados." (NERY JÚNIOR; NERY, 2006, p.553). ${ }^{14}$

$\mathrm{O}$ contrato de seguro tem por finalidade, a transferência do risco existente na atividade econômica desenvolvida pelo segurado à sociedade especializada (seguradora), que se obriga, mediante certa contribuição em pecúnia avençada no contrato de seguro (prêmio), a garantir interesse legítimo segurável, relativo a bens ou pessoas contra riscos previstos no contrato.

Esse é classificado conforme a natureza do risco segurável, sendo subdividido em duas categorias previstas no Código Civil de 2002, a saber: a dos seguros de danos ou dos ramos elementares (artigo 778 a $788 \mathrm{CC} / 02$ ) e a dos seguros de pessoa (artigo 789 a 802 $\mathrm{CC} / 02)$.

No contrato de seguro, a observância ao princípio da boa-fé objetiva é fundamental, pois se caracteriza como elemento essencial ${ }^{15}$, direcionador das relações jurídicas obrigacionais advindas do arcabouço jurídico desse contrato (THEODORO JÚNIOR, 2004, p. 22-23), no intuito de orientar a atuação das partes na relação securitária, conforme previsão legal do artigo 765 do Código Civil de $2002^{16}$, em consonância com o sentido estabelecido nos artigos 113, 187 e 422 do Código Civil de 2002 e 4, III e 51, IV do Código de Defesa do Consumidor, os quais informam a base principiológica da boa-fé objetiva no Direito Privado.

É um padrão de conduta imposto aos contratantes (segurado e segurador), durante todo o vínculo contratual, no tocante ao objeto, circunstâncias e declarações (informações) relativas à conclusão e execução do contrato de seguro, evidentemente, não se olvidando da fase pré-contratual e pós-contratual. ${ }^{17}$

14 Acerca da definição jurídica do contrato de seguro, remete-se ao estudo da doutrina abalisada: ALVIM (2007, p.5-7); DINIZ (2003, p.488); DINIZ (2006, p.525); GUERREIRO (2004, p.7); MARENSI (2007, p.82); MARTINS (2005, p.5); MATOS; MOLINA (2006, p.31-33); SHIH (2003, p.42-43); TAVARES (2004).

15 Sergio Cavalieri Filho preconiza que três são os elementos essenciais do contrato de seguro, quais sejam: o risco, a mutualidade e a boa-fé, os quais formam o tripé do seguro, ou, em outras palavras, uma verdadeira trilogia do seguro (CAVALIERI FILHO, 2007, p.404).

16Artigo $765 \mathrm{CC} / 02$ : “O segurado e o segurador são obrigados a guardar na conclusão e na execução do contrato, a mais estrita boa-fé e veracidade, tanto a respeito do objeto como das circunstâncias e declarações a ele concernentes."

17 José Augusto Delgado assevera que “[...] o segurado se obriga a descrever com clareza e precisão a natureza do risco que deseja cobrir, assim como ser verdadeiro em todas as declarações posteriores, relativas a possíveis alterações do risco ou a ocorrência de sinistro. O segurador, por seu lado, é obrigado a dar informações exatas sobre o contrato e redigir o seu conteúdo de forma clara para que o segurado possa compreender os compromissos assumidos por ambas as partes. [...] As partes obrigam-se a atuar de modo que as suas declarações exprimam a mais absoluta verdade. Devem declarar os fatos com exatidão e realidade, a fim de que os efeitos do contrato de seguro não gerem vantagens indevidas e contrárias ao direito." (DELGADO, 2004, p.83-84). Para maiores informações sobre a correlação entre boa-fé objetiva e o contrato de seguro ver: MARTINS (2005, p.3); SANTOS (2006, p.82); CAVALIERI FILHO (2002, p.215); CAVALIERI FILHO (2007, p.416); NERY JÚNIOR (2002, p.185); GUERREIRO (2004, p.24-25).

Revista da Faculdade Mineira de Direito, v.12, n. 23, jan./jun. 2011 - ISSN 1808-9429. 
Esse é o sentido visado pelo artigo 765 do Código Civil, o qual consagrou, expressamente, o princípio da boa-fé objetiva no contrato de seguro, tendo assim sua observância, e, por conseguinte, de suas funções e deveres anexos, imposta aos contratantes, com a finalidade de garantir o adimplemento contratual e a percepção da justiça contratual.

Deste modo, a boa-fé objetiva possui no contrato de seguro, função ainda mais relevante, pois por imposição legal é expressa e substancialmente consagrada no referido contrato, tendo em sua aplicação papel indispensável na relação jurídica, no intuito de resguardar os contratantes, durante todo o vínculo contratual. ${ }^{18}$

A inserção da boa-fé objetiva no momento de celebração do contrato de seguro de automóveis é fundamental, no intuito de estabelecer direitos e obrigações relacionados ao contrato, tendo o dever de informar e a transparência, aplicação destacada no tocante a apresentação de todas informações, efetivamente necessárias, para conclusão do contrato (SANTOS, 2006, p.81).

Em relação à incidência da legislação consumerista ao contrato de seguro, a aplicação da boa-fé objetiva exige maior habilidade do intérprete, vez que sua plenitude somente será alcançada se não houver infração de preceitos protetivos do Direito do Consumidor, os quais incidem diretamente sobre o contrato de seguro segundo previsão legal dos artigos $3^{\circ}, \S 2^{\circ}, 4$, III e 51, IV do Código de Defesa do Consumidor (SHIH, 2003, p.27).

Nos casos de ocorrência de sinistro, e pendente alguma divergência, a interpretação a ser realizada no contrato de seguro é sempre restritiva, e favorável ao segurado, por tratar-se de contrato de adesão, conforme os artigos 46, 47 e 54 do Código de Defesa do Consumidor.

Portanto, segurado e segurador devem pautar-se numa conduta sincera e leal, a qual deve nortear o tráfico jurídico, conforme os usos e costumes sociais, ressaltando-se, ainda, as exigências de boa-fé e veracidade em relação ao contrato de seguro, principalmente, no que concerne às informações (declarações), circunstâncias e riscos, relacionados ao conteúdo do referido contrato, sob pena de ofensa ao referido princípio (KRIGER FILHO, 2000, p.85; TZIRULNIK; CAVALCANTI; PIMENTEL, 2002, p.68-69).

\section{CONTRATO DE SEGURO DE VIDA}

\footnotetext{
18 Nesse sentido, Domingos Afonso Kriger Filho expõe que "Se a boa-fé se faz imprescindível nos contratos em geral, com mais razão deve se fazer presente no contrato de seguro, tendo em vista que a sinceridade e a verdade constituem-se na base primeira da declaração de vontade que o origina. [...] A boa-fé exigida [...] é a boa-fé lealdade ou objetiva, vale dizer, aquela em que não há necessidade de se perquerir a intenção do agente, mas a que leva em conta apenas a sinceridade que deve servir de parâmetro no comércio jurídico, segundo padrão de usos sociais e bons costumes, sendo que sua observância se faz imprescíndivel não só no momento de celebração do contrato, mas se estende igualmente até a sua execução.(KRIGER FILHO, 2000, p.83-84).
}

Revista da Faculdade Mineira de Direito, v.12, n. 23, jan./jun. 2011 - ISSN 1808-9429. 
O contrato de seguro de vida apresenta-se como uma das espécies do seguro de pessoas, possuindo regramento legal previsto nos artigos 789 a 802 do Código Civil de 2002.

Trata-se de modalidade de contrato de seguro pela qual "o segurador se obriga, em contraprestação ao recebimento do prêmio, a pagar ao próprio segurado ou a terceiro determinada quantia sob a forma de capital ou de renda, quando da verificação do evento danoso." (GUERREIRO, 2004, p.128). ${ }^{19}$

O contrato de seguro de vida foi consagrado através do Código de Defesa do Consumidor como uma relação jurídica de consumo, em face atividade securitária ser erigida no ordenamento jurídico brasileiro como sendo uma prestação de serviço ${ }^{20}$, conforme previsão legal esculpida no artigo $3^{\circ}, \S 2^{\circ}$ do o Código de Defesa do Consumidor (MARQUES, 2006, p.503). Portanto, o referido contrato encontra-se adstrito, precipuamente, à legislação consumerista, e, principalmente, às diretrizes estabelecidas na Política Nacional das Relações de Consumo (artigo $4^{\circ} \mathrm{CDC}$ ), sendo os ditames legais da proteção do consumidor plenamente aplicáveis à atividade securitária.

O Supremo Tribunal Federal, no julgamento da ADI n 2.591-1/DF, consolidou e pacificou esse posicionamento, ao reafirmar que o contrato de seguro encontra-se sob a égide do Código de Defesa do Consumidor, como já, expressamente evidenciado, pelo artigo $3^{\circ}, 2^{\circ}$ do CDC, devendo, portanto, orientar-se segundo as diretrizes da legislação consumerista, fundada em normas de ordem pública e de interesse social (BRASIL, STF, 2006; CARVALHO, 2007, p. 191-355; BENJAMIN; MARQUES; BESSA, 2007, p.26-27).

Assim sendo, o Código de Defesa do Consumidor em consonância com o Código Civil de 2002, passou a regulamentar e nortear, as relações jurídicas securitárias, no intuito de tutelar o segurado, parte vulnerável, bem como servir de instrumento de equilíbrio das relações de consumo no âmbito contratual, de modo a modificar determinadas posturas impostas pelos seguradores em face aos segurados, via de regra, abusivas.

Nesse sentido, a legislação consumerista consagrou a proteção contratual ao segurado, através da previsão legal do artigo 46 CDC, o qual impõe, nos contratos, a observância dos princípios da boa-fé objetiva e da transparência em sua formação; do artigo 47 CDC, que se

19 Acerca da definição jurídica do contrato de seguro de vida, remete-se ao estudo da doutrina abalisada: ALVIM (2007, p. 149-152); MARTINS (2005, p. 132-133).

20 Art. $3^{\circ} \mathrm{CDC}$ : "Fornecedor é toda pessoa física ou jurídica, pública ou privada, nacional ou estrangeira, bem como os entes despersonalizados, que desenvolvem atividades de produção, montagem, criação, construção, transformação, importação, exportação, distribuição ou comercialização de produtos ou prestação de serviços; $\S 2^{\circ}$ : Serviço é qualquer atividade fornecida no mercado de consumo, mediante remuneração, inclusive as de natureza bancária, financeira, de crédito e securitária, salvo as decorrentes das relações de caráter trabalhista.”

Revista da Faculdade Mineira de Direito, v.12, n. 23, jan./jun. 2011 - ISSN 1808-9429. 
traduz na interpretação mais favorável ao consumidor; no controle exercido em face das cláusulas abusivas (artigo 6º IV e 51 CDC) e contratos de adesão (artigo 54 CDC).

$\mathrm{O}$ seguro de vida tem por objetivo garantir os riscos atinentes à duração da vida humana, e para tanto deve ser precedido de declarações do segurado sobre determinadas circunstâncias (estado de saúde, idade, atividade profissional) sendo que nessa ótica, a análise do risco pela seguradora possui grande importância para mensuração do prêmio a ser pago (TZIRULNIK; CAVALCANTI; PIMENTEL, 2002, p. 168-169; SANTOS, 2006, p.85).

Desta forma, o risco, acontecimento possível, mas futuro e incerto, e a boa-fé objetiva são elementos primordiais no contrato de seguro de vida (ALVIM, 1999, p. 257). Isto porque, as informações sobre o segurado são obtidas através da proposta e do formulário denominado declaração de saúde, que deve ser preenchida e assinada pelo mesmo, os quais servirão de parâmetro para a mensuração do risco e cálculo do valor do prêmio.

[...] Sabe-se que risco é, antes de tudo, percepção individual. Por isso, as perguntas do questionário devem ser objetivas o bastante de modo a não permitir dubiedade nas respostas. Deve ser evitada qualquer pergunta que privilegie considerações de natureza subjetiva. É sabido que, pairando dúvidas que possam acarretar o não cumprimento da obrigação, decidir-se-á em favor do aderente (segurado). (MARTINS, 2005, p. 41).

Deste modo, a observância precípua da boa-fé objetiva pelo segurado, notadamente, em relação ao dever de informar, é indispensável na conclusão do contrato de seguro de vida, sob pena de perda do seguro, conforme previsão legal do artigo 766 Código Civil de 2002. ${ }^{21}$

Por este motivo, as seguradoras discutem a impossibilidade de pagamento das indenizações, quando as informações prestadas pelo segurado deixam de eleger toda a extensão do risco a que estarão no futuro, porventura, sujeitos.

Neste contexto destaca-se um dos maiores problemas que envolvem o contrato de seguro de vida, a chamada doença preexistente, pois fica ao alvedrio da seguradora, se julgar necessário, realizar exames médicos para verificar as condições de saúde em que se encontra o segurado no ato da contratação, e, por conseguinte, poder mensurar adequadamente o risco.

Portanto, o segurado deve fazer declarações verdadeiras e completas, de modo a não omitir circunstâncias que possam influir na aceitação da proposta ou na mensuração do risco e, em conseqüência, na fixação da taxa do prêmio, sob pena de perder o direito ao valor do

21 Artigo $766 \mathrm{CC} / 02$ : “Se o segurado, por si ou por seu representante, fizer declarações inexatas ou omitir circunstâncias que possam influir na aceitação da proposta ou na taxa do prêmio, perderá o direito à garantia, além de ficar obrigado ao prêmio vencido. Parágrafo único: Se a inexatidão ou omissão nas declarações não resultar de má-fé do segurado, o segurador terá direito a resolver o contrato, ou a cobrar, mesmo após o sinistro, a diferença de prêmio.”. 
seguro e pagar o prêmio vencido. ${ }^{22}$ No contrato de seguro de vida, a observância ao princípio da boa-fé objetiva entre os contratantes é essencial ao adimplemento contratual.

O segurado, ao contratar o seguro de vida, é obrigado a informar à seguradora sua condição de saúde, bem como a existência ou não de doenças preexistentes e demais circunstâncias, as quais, interferem na avaliação do risco e mensuração do prêmio.

Destarte, conforme previsão dos artigos 765 e 766 caput e parágrafo único Código Civil de 2002, se houver ofensa da boa-fé objetiva por parte do segurado, este estará sujeito às penalidades legais. Nesse sentido, o segurado poderá ter negado o atendimento ao sinistro, e, por conseguinte, poderá ainda perder o direito à indenização. ${ }^{23}$

Assim, a boa-fé objetiva incidente sobre os contratos de seguro, requer uma conduta sincera e leal do segurado no que concerne às declarações sobre os riscos incidentes sobre a pessoa do segurado, sob pena de sofrer severas sanções se proceder à quebra da boa-fé ou omitir, mesmo que involuntariamente, alguma informação.

Lado outro, por imposição da boa-fé objetiva (artigos 4, III, 51, IV CDC, 422 e 765 CC/02) e preceitos erigidos no Código de Defesa do Consumidor ligados ao dever de informar e ao direito à informação do consumidor (artigo $4^{\circ}$, IV e $6^{\circ}$, III CDC) é dever da seguradora informar, previamente ao segurado, de forma clara, ostensiva, precisa e adequada, sobre todas suas condições, cláusulas limitativas, possiveis exclusões de responsabilidade e termos técnicos relacionados ao contrato de seguro firmado, sob pena de quebra da boa-fé objetiva, e de interpretação favorável ao segurado, ao teor do artigo 47 do Código de Defesa do Consumidor (KRIGER FILHO, 2000, p.99-100). ${ }^{24}$

Nesse sentido, é fundamental a observância do princípio da boa-fé objetiva pelos contratantes, na concessão de informações mútuas acerca do conteúdo contratual, pois o referido princípio permeia e orienta o contrato de seguro de vida.

Logo, o dever de informar impõe aos contratantes prestar informações corretas, adequadas e transparentes sobre todas as circunstâncias relacionadas ao contrato, tanto em sua formação quanto em sua execução, com vistas ao adimplemento, em observância aos preceitos da boa-fé objetiva (NERY JÚNIOR, 2002, p. 174).

22 Em relação à relevância da mensuração risco no cálculo do valor do prêmio do contrato de seguro ver: TZIRULNIK; CAVALCANTI; PIMENTEL (2002, p.30-31).

23 Paulo Luiz Netto Lôbo ao comentar o artigo 766 do Código Civil, expõe que "Consoante regra constante do artigo, o segurado perde o direito à indenização que lhe corresponde, na hipótese de se valer de informações imprecisas. Todavia, tal regra não é absoluta, posto que se tal relação for considerada de consumo, o ônus será invertido, cabendo à seguradora provar que o segurado omitiu situações ou fez declarações inexatas. (LÔBO, 2004, p.506). Nesse mesmo sentido ver: CAVALIEIRI FILHO (2002, p.215-216); TAVARES (2004).

24 Nesse mesmo sentido ver: MARQUES (2006, p.228-229).

Revista da Faculdade Mineira de Direito, v.12, n. 23, jan./jun. 2011 - ISSN 1808-9429. 
É importante destacar que a previsão legal do artigo 766, parágrafo único, do Código Civil, tem-se como extremamente vantajosa as seguradoras, ao impor aos segurados posição de patente inferioridade, pelo que sua interpretação deve ser realizada em consonância com os ditames fundamentais elencados no Código de Defesa do Consumidor e no Código Civil.

\subsection{Contrato de seguro de vida: contrato tipicamente de adesão}

O contrato de seguro de vida é um contrato tipicamente de adesão $0^{25}$, devido ao fato do segurado contratá-lo, de acordo com cláusulas previamente definidas pelo segurador na apólice, regulamentadas e aprovadas pela SUSEP, aceitando ou não, em bloco, as condições impostas na proposta formalizada.

Nos contratos de adesão, não há mais lugar para negociações e discussões acerca de cláusulas contratuais, pois a massificação dos contratos, imposta através de cláusulas adesivas e pré-determinadas em formulários impressos, modificou toda a realidade das contratações, permitindo aos conglomerados econômicos reduzir custos e otimizar o processo produtivo, para permitir contratações mais céleres (FIUZA, 2006, p.406; RIZZARDO, 1995, p.85).

Nessa esteira, os consumidores aderem a contratos pré-redigidos, padronizados, sem que possam ter conhecimento prévio, claro e preciso do conteúdo contratual, pois não tem a oportunidade de ler e ponderar, com precaução, sobre as cláusulas que lhe são impostas.

$\mathrm{Na}$ maioria dos casos, o consumidor somente recebe o contrato após concluí-lo, e soma-se a isso a falta de conhecimento para entender os termos técnicos do contrato (vulnerabilidade técnica), acrescidos a conteúdos extensos, impressos em letras de tamanho reduzido, que visam a desestimular a leitura e análise do conteúdo contratual pelo aderente (MARQUES, 2006, p.160).

Ademais, há a imposição de várias cláusulas limitativas da contratação, as quais não são explícitas, e ao contrário, por vezes encontram-se inseridas sem qualquer destaque, o que impede a verificação das mesmas no instrumento contratual.

Desse modo, a interpretação destas situações adquire grande importância na contemporaneidade, com a inserção nas relações de consumo, do princípio da boa-fé objetiva,

\footnotetext{
25Claudia Lima Marques expõe que "Contrato de adesão é aquele cujas cláusulas são preestabelecidas unilateralmente pelo parceiro contratual economicamente mais forte (fornecedor), ne varietur, isto é, sem que outro o outro parceiro (consumidor) possa discutir ou modificar substancialmente o conteúdo do contrato escrito. Desta maneira, limita-se o consumidor a aceitar em bloco (muitas vezes sem sequer ler completamente) as cláusulas que foram unilateral e uniformemente pré-elaboradas pela empresa, assumindo, assim, um papel de simples aderente à vontade manifestada pela empresa no instrumento contratual massificado.” (MARQUES, 2006, p.71); Nesse sentido, FIUZA; ROBERTO (2002, p.68); TARTUCE (2007, p.306); GOMES (2007, p.128).
}

Revista da Faculdade Mineira de Direito, v.12, n. 23, jan./jun. 2011 - ISSN 1808-9429. 
e em decorrência deste, o princípio da transparência e o dever de informar sobre o conteúdo do contrato, bem como à observância a função social dos contratos e a justiça contratual.

É o sentido que direcionou os artigos 46 e 47 do Código de Defesa do Consumidor ${ }^{26}$, e o artigo 423 do Código Civil de $2002^{27}$, que prevêem a interpretação dos contratos de forma mais favorável ao aderente/consumidor, no intuito de resguardá-lo, em caso de eventual arbitrariedade praticada pelo proponente.

O contrato de seguro apresenta-se como um dos exemplos mais comuns de contratos de adesão, em face do dinamismo da atividade securitária, da massificação dos contratos e da necessidade de rapidez, na conclusão das relações contratuais securitárias.

Todavia, inúmeras críticas são delineadas em relação à formação do contrato de seguro, principalmente, quanto à falta de liberdade contratual no tocante à estipulação do conteúdo do referido contrato, a qual impõe aos segurados condições por vezes, excessivamente, onerosas. Destaca-se que, geralmente, os segurados aderem aos contratos sem que possam ter informações necessárias e suficientes acerca do conteúdo contratual, de seus direitos e obrigações, conjugado ao fato do contrato trazer em seu bojo exacerbado tecnicismo, dificultando, assim, a compreensão dos termos do instrumento contratual.

$\mathrm{O}$ fato de ser o contrato redigido pelo segurador, aliado à sua natureza técnica pouco acessível ao segurado, deixou este praticamente à mercê daquele para impor um caráter quase unilateral ao negócio. A igualdade jurídica dissimula uma desigualdade de fato. (ALVIM, 1999, p.133).

Essa é situação que permeia o contrato de seguro de vida, onde há patente desequilíbrio na relação contratual e, por conseguinte, posição de inferioridade do segurado em face do segurador, no tocante à estipulação do conteúdo do referido contrato.

Nos contratos de seguro e de previdência privada, em inúmeras cláusulas derrogam-
se os princípios do Código de Defesa do Consumidor [...]. Constitui o setor em
estudo um daqueles em que mais dominam as injustiças e os engodos praticados
pelas entidades patrocinadoras. A observar-se com rigor as cláusulas, seguramente
cerca de metade das mesmas não revelaria condições de validade. Sistematicamente
as pessoas ficam lesadas, tudo sob o dogma do pacta sunt servanda, e de que os
incautos subscritores assinaram aceitar o contrato e tiveram conhecimento do
regulamento geral. [...] As propagandas e vantagens oferecidas em anúncios e capas
dos regulamentos ou das apólices constituem um verdadeiro engodo. [...] Além de
serem as cláusulas de difícil intelecção, não trazem qualquer garantia no tocante ao
valor pagável. [...] Outras formas de chamar a atenção irradiam em convites

26Artigo 46 CDC - "Os contratos que regulam as relações de consumo não obrigarão os consumidores, se não lhes for dada a oportunidade de tomar conhecimento prévio de seu conteúdo, ou se os respectivos instrumentos forem redigidos de modo a dificultar a compreensão de seu sentido e alcance."

Artigo 47 CDC - "As cláusulas contratuais serão interpretadas de maneira mais favorável ao consumidor."

27 Artigo 423 CC/02 - “Quando houver no contrato de adesão cláusulas ambíguas ou contraditórias, dever-se-ão adotar a interpretação mais favorável ao aderente."

Revista da Faculdade Mineira de Direito, v.12, n. 23, jan./jun. 2011 - ISSN 1808-9429. 
atraentes - como "o plano foi idealizado para proporcionar-lhe total segurança", ou "plano de assistência médica global" - quando inúmeras as restrições e raros os riscos cobertos. A propaganda, ou o anúncio, engana e ilude o interessado infringindo-se, dentro outros preceitos, o art. 37, inc. I, por omissão sobre a realidade dos benefícios. (RIZZARDO, 1995, p. 87, 100-101).

Assevera-se que o segurado, via de regra é leigo, sendo que não possui conhecimentos a fim de compreender o conteúdo contratual (vulnerabilidade técnica, jurídica), possuindo pouco ou quase nenhum acesso a informações claras, precisas e transparentes sobre o contrato (vulnerabilidade informativa) e, ainda, avença com seguradoras que representam grandes conglomerados econômicos (vulnerabilidade econômica), o que lhe impõe posição de evidente inferioridade perante aos mesmos na contratação do seguro.

E tal situação é de ocorrência cotidiana nas contratações que envolvem o contrato de seguro, pois os segurados assinam as propostas de seguro, sem que possuam prévio e completo conhecimento das condições gerais do contrato, as quais somente lhe são apresentadas, a posteriori, no ato de entrega da apólice de seguro pelas seguradoras.

Clarividente que a obrigação do segurador é informar ao segurado sobre todo o conteúdo contratual, no ato da contratação, e, sobretudo, entregar-lhe o contrato, e sanar toda e qualquer dúvida, inclusive técnica, acerca das condições gerais do seguro a ser contratado.

Porém, não é o que ocorre na prática destas contratações, que impõem aos segurados condições precárias para firmarem os contratos, e, por conseguinte, demandando um maior controle estatal acerca da imposição de cláusulas abusivas e do próprio processo de formação dos contratos de seguro pelas seguradoras, a partir da interpretação do contrato de forma mais favorável aos segurados, conforme o artigo 47 do Código de Defesa do Consumidor.

\footnotetext{
As regras de interpretação das quais dependa a determinação da prestação a cargo do segurador, a seu turno, serão guiadas pelo princípio "in dúbio pro segurado", segundo o qual as dúvidas devem solver-se em favor do segurado, princípio antiqüíssimo do direito obrigacional securitário. (TZIRULNIK, 2001, p. 41). ${ }^{28}$
}

E tal preceito justifica-se no fato de que o segurador é quem apresenta ao segurado formulários pré-impressos, com cláusulas previamente definidas, que transformam o contrato de seguro em verdadeiro contrato de adesão e, portanto, essas cláusulas devem sempre ser interpretadas, quando ambíguas ou de conteúdo duvidoso, contra quem as produziu (CARVALHO, 2007, p.4; BENJAMIN; MARQUES; BESSA, p.290-291).

O Código de Defesa do Consumidor e o Código Civil de 2002, fundados na nova principiologia contratual, são instrumentos hábeis e fundamentais a tutelar, o contrato de 
seguro, enquanto relação de consumo. Por tratar-se de um contrato de adesão, deve ser interpretado de maneira mais favorável ao segurado, que se encontra em posição de inferioridade em relação ao segurador, no intuito garantir o reequilíbrio contratual.

\subsection{A doença preexistente nos contratos de seguro de vida}

O conceito de doença preexistente é utilizado pelas seguradoras, visando a resguardar sua atividade econômica, por meio de exclusões de doenças em relação aos seguros firmados, seja de saúde ou mesmo de vida.

As cláusulas contratuais que impõe a exclusão de doenças preexistentes no contrato de seguro de vida, sem o prévio exame médico das condições de saúde do segurado, e prestação de informações adequadas sobre a exclusão do seguro, visam meramente a transferir o risco da atividade econômica ao segurado, e, por conseguinte, são tidas como cláusulas abusivas. ${ }^{29}$

Como na maioria dos casos, no ato da contratação do seguro, não há a realização de exame médico prévio, entende-se que se impõem as seguradoras os ônus de suportar os riscos contratuais advindos de sua atividade econômica, pois poderia ter-se precavido e não o fez.

O segurado, ao realizar a contratação, tem seus interesses tutelados pelo princípio da boa-fé objetiva, que preconiza que as expectativas razoáveis criadas pelo fornecedor, em razão do produto/serviço oferecido, passam a ter que ser fielmente seguidas, posto que se vinculam ao instrumento contratual.

O grande desafio do Judiciário está na descoberta do fator boa-fé (arts. $4^{\circ}$, III, da Lei 8.078/90 e 422, do NCC), uma questão tormentosa e que, invariavelmente, provoca dissidência entre os juízes, notadamente quando versar sobre o dever de informar doença pré-existente. Não há, ainda, consenso acerca desse ponto, embora prevaleça a tese, fundada no art. 47, da Lei n ${ }^{\circ}$ 8.078/90, de que eventual má-fé do aderente, na hora de preencher o questionário sobre suas condições de saúde (quando omite padecer de ales conhecidos), não tem relevância jurídica, por ser obrigação da seguradora ou dos operadores de plano de saúde realizar prévios exames médicos para aferir a aptidão física da pessoa com que contrata. (ZULIANI, 2004, p.47).

Nessa esteira, a jurisprudência dos Tribunais Pátrios acolhe a possibilidade de flexibilização da interpretação dessas informações, no sentido de admitir:

a) as doenças de convívio, que não fossem causa do óbito do segurado;

29 Nelson Nery Júnior explicita que “[...] cláusula abusiva é aquela que é notoriamente desfavorável à parte mais fraca na relação contratual, que, no caso de nossa análise, é o consumidor, aliás, por expressa definição do art. $4^{\circ}$, n. ${ }^{\circ}$ I, do CDC. A existência de cláusula abusiva no contrato de consumo torna inválida a relação contratual pela quebra do equilíbrio entre as partes, pois normalmente se verifica nos contratos de adesão, nos quais o estipulante se outorga todas as vantagens em detrimento do aderente, de quem são retiradas as vantagens e a quem são carreados todos os ônus derivados do contrato." (GRINOVER, et al., 2007, p.569).

Revista da Faculdade Mineira de Direito, v.12, n. 23, jan./jun. 2011 - ISSN 1808-9429. 
b) a doença preexistente desconhecida pelo segurado, cuja presunção de boa-fé decorreria a favor do segurado;

c) o preceito de que a má-fé do segurado alegada teria de ser comprovada pela seguradora.

Processo Civil - Embargos Infringentes - Cobrança de Seguro de Vida - Doença Preexistente à Contratação do Seguro - Ausência de Comprovação da Má-Fé do Segurado - Indenização Securitária devida. A Seguradora que concretiza o seguro e recebe o prêmio, sem efetuar o questionamento prévio sobre o estado de saúde do contratante, deve responder pelo risco assumido, não podendo se esquivar da indenização, sob a alegação de doença preexistente, já que não provou a má-fé do segurado. (MINAS GERAIS, Tribunal de Justiça, 2008). ${ }^{30}$

Ação de cobrança. Seguro de vida. Negativa de pagamento. Elementos probatórios que quebram a existência de relação entre a doença preexistente e a causa mortis. Omissão do segurado sobre estado de saúde. Não realização de exames médicos prévios. Seguradora assume os riscos do negócio pela negligência. Não comprovada a relação entre a doença preexistente e àquela causadora da morte do segurado, considera-se hígido o contrato, mantendo-se o dever de indenizar da seguradora. [...] (SANTA CATARINA, Tribunal de Justiça, 2006). ${ }^{31}$

Nesse sentido, o Superior Tribunal de Justiça firmou entendimento "de que a seguradora que não exigiu a realização de exames médicos prévios à celebração do contrato de seguro de vida não pode se escusar do pagamento alegando omissões do segurado sobre doença preexistente, salvo a existência de comprovada má-fé por parte do segurado". (BRASIL, Superior Tribunal de Justiça, 2007).

\begin{abstract}
Direito civil. Recurso especial. Agravo no agravo de instrumento. Seguro de vida. Legitimidade passiva. Súmulas 5 e 7/STJ. Responsabilidade exclusiva da seguradora. Ausência de prequestionamento. Doença preexistente. Nãodemonstração de má-fé do segurado. Necessidade de prévio exame médico ou prova da efetiva má-fé do segurado. Súmula 83/ STJ. Súmula 7/STJ. Dano moral. Dissídio não comprovado. Em sede de recurso especial, não se admite a interpretação de cláusulas contratuais nem o reexame de matéria de fato. É vedado o reexame do acervo-fático probatório em sede especial de recurso. O prequestionamento dos dispositivos legais tidos como violados constitui requisito de admissibilidade do recurso especial. Nos termos da jurisprudência dominante deste Tribunal, a doença preexistente pode ser oposta pela seguradora ao segurado apenas se houver prévio
\end{abstract}

30 Nesse mesmo sentido, ver: Apelação Cível - Cobrança - Seguro - Renda Por Invalidez - Aplicação do CDC Alegação de Doença Preexistente - Má-Fé do Segurado - Não Comprovação- Indenização Devida - O contrato de seguro se submete aos preceitos do CDC, devendo ser interpretado da forma mais favorável ao segurado, observando-se os princípios da boa-fé, transparência, dever de informação e equidade. - Embora exista no contrato cláusula limitativa expressa de doença preexistente, não tendo a seguradora comprovado a má-fé do segurado no momento da contratação, comprovando ter o segurado realizado declarações falsas ou não tendo realizado exames prévios à contratação, presente está o dever de indenizar, assumindo os riscos de sua atividade negocial. (MINAS GERAIS, Tribunal de Justiça, 2007).

31 Nesse mesmo sentido, ver: Tribunal de Justiça de Santa Catarina, Segunda Câmara de Direito Civil, Apelação Cível no 2004.002877-6, Rel. Des. Mazoni Ferreira. Julgamento 07/07/2005; Tribunal de Justiça de Santa Catarina, Segunda Câmara de Direito Civil, Apelação Cível no 2004.017432-2, Rel. Des. Luiz Carlos Freyesleben. Julgamento 27/10/2005. Disponíveis: em: <http://tjsc6.tj.sc.gov.br/jurisprudencia/PesquisaAvancada.do>. Acesso em: 04 abr. 2008.

Revista da Faculdade Mineira de Direito, v.12, n. 23, jan./jun. 2011 - ISSN 1808-9429. 
exame médico ou prova inequívoca da má-fé do segurado. Necessário que o recorrente promova o confronto analítico e demonstre a similitude fática entre as hipóteses comparadas para o conhecimento do recurso especial com fundamento na alínea "c" do permissivo constitucional. Agravo não provido. (BRASIL. Superior Tribunal de Justiça, 2007, grifo nosso). ${ }^{32}$

Portanto, a partir da concepção contemporânea do princípio da boa-fé objetiva, consolidou-se o entendimento de que caberia aos seguradores realizarem prévio exame médico no momento da assinatura do contrato de seguro de vida para resguardar-se de riscos advindos da atividade securitária, relacionados à doença preexistente.

Tal fato fundamenta-se se na acintosa publicidade, muitas vezes enganosa, a qual visa a induzir o segurado a erro, pela qual às seguradoras obtém elevados lucros, e, por conseguinte, devem conseqüentemente, suportar os riscos decorrentes da atividade empresarial desenvolvida, sob pena de se imputar todos os ônus relativos ao contrato firmado, aos segurados, os quais, na maioria das vezes, recebem pouca, ou quase nenhuma informação adequada para celebrarem o contrato de seguro de vida.

Assim, reitera-se o entendimento esposado acerca da necessidade de observância do princípio da boa-fé objetiva, na prestação das informações necessárias à formação do contrato de seguro, principalmente, em relação às cláusulas limitativas, exclusões de responsabilidade e termos técnicos relacionados ao contrato de seguro de vida.

Portanto, é imprescindível que o dever de informação seja observado pelos contratantes (segurado e segurador), visando ao equilíbrio contratual, em atenção ao princípio da boa-fé objetiva, transparência e preceitos do Código de Defesa do Consumidor.

\footnotetext{
$\mathrm{Na}$ verdade o que constantemente vem se repetindo são impróprias exigências formuladas pelas Companhias Seguradoras no momento de pagamento da indenização. Exigência como a alegada na peça contestatória teria sentido, em princípio, na fase pré-contratual e não no momento de honrar o compromisso pactuado. Acontece porém, que os corretores na ânsia de recebimento de comissão e inclusive incentivados pelas próprias seguradoras, interessadas na elevação de suas respectivas carteiras, não cumprem com rigor a fase anterior à celebração da apólice. $\mathrm{O}$ que o direito não admite é que ocorrido o sinistro queiram fugir totalmente de suas obrigações financeiras alegando algumas motivações já preclusas ou sem qualquer instrumento probatório como no caso presente. [...] Como bem disse a julgadora de primeiro grau, o entendimento predominante em nossa jurisprudência é no sentido de inexistência de comprovação de doença pré-existente. É notório que incidente a presunção de boa fé nos contatos de seguro, sendo que a pré-existência de doenças ditas mortais devem acontecer quando da celebração do seguro e não no momento do pagamento da indenização, principalmente quando o seguro sobrevive por largo tempo da celebração e em dias que o Código de 2002 acrescenta a predominância do princípio da boa fé. (BRASIL, Superior Tribunal Justiça, 2006).
}

32 Nesse mesmo sentido, ver: Superior Tribunal de Justiça, Terceira Turma, Recurso Especial $\mathrm{n}^{\circ}$ 651713/PR (2004/0048250-1), Rel. Min. Carlos Alberto Menezes Direito. Julgamento 12/04/2005. Disponível em: <http://www.stj.jus.br/SCON/jurisprudencia/toc.jsp?livre=(('RESP'.clap.+ou+'RESP'.clas.)+e+@ @um='651713 ')+ou+('RESP'+adj+'651713'.suce.)>. Acesso em: 04 abr. 2008; 
O que se verifica na prática, é que as seguradoras, aceitam firmar o contrato de seguro de vida, recebem as parcelas do prêmio, sem realizarem o devido e necessário exame médico sobre a saúde do segurado, como forma de se resguardarem seus interesses econômicos, para posteriormente, exonerarem-se da contraprestação prevista no contrato, e assim, configurar o enriquecimento sem causa das seguradoras em face aos segurados.

O problema reside no seguinte fato: ao finalizar um contrato de vida deveria ser exigido do segurado, vários exames médicos para detectar a álea respectiva e quantificar o prêmio, eliminando a questão de ser ou não doença preexistente à contratação, bem como se o segurado teve ou não má-fé, omitindo a doença. Diante dos diagnósticos médicos não restariam dúvidas. Desde o início seria evidente a álea, sendo certeiro o cálculo atuarial do prêmio, pois já incluiria o risco assumido. (CECCONELLO, 2001, p. 16).

Evidentemente, tais problemas poderiam ser sanados, se as seguradoras tivessem, por precaução, a realização de exame médico prévio, sob as condições de saúde dos segurados antes da contratação, evitando-se, desta forma, os ônus contratuais decorrentes dos riscos da atividade securitária, extremamente lucrativa para as seguradoras.

\section{CONCLUSÃO}

Com o advento do Código de Defesa do Consumidor (1990), e, posteriormente, do Código Civil (2002), as relações contratuais tomam novo impulso, com inserção da nova principiologia contratual no Direito Privado, com destaque para o princípio da boa-fé objetiva, que passa a relativizar a autonomia privada dos contratantes, apresentando novos contornos à liberdade contratual, no tocante ao estabelecimento do conteúdo do contrato.

A reinterpretação dos contornos do Direito Contratual contemporâneo deve ser realizada a partir das circunstâncias apresentadas pelo caso concreto, com base na imprescindível abordagem principiológica presente no Direito Privado.

O mesmo deve ocorrer com o contrato de seguro de vida, que em face de sua relevância no Direito Securitário, ligada, diretamente, à utilidade econômica do referido contrato na sociedade, demanda uma releitura do modelo jurídico, para adequá-lo aos novos contornos do Direito Contratual na contemporaneidade.

Nas relações securitárias, a boa-fé objetiva apresenta-se como elemento essencial e direcionador da conduta das partes, notadamente, no momento de celebração do contrato, tendo o dever de informação, o princípio da transparência e o direito à informação, aplicação destacada no tocante à apresentação de todas as informações, efetivamente, necessárias para a conclusão do contrato, principalmente, pelo fato de tratar-se de um contrato de adesão.

Revista da Faculdade Mineira de Direito, v.12, n. 23, jan./jun. 2011 - ISSN 1808-9429. 
Por tratar-se de uma relação de consumo, o contrato de seguro de vida, deve ser interpretado de maneira mais favorável ao segurado, o qual se encontra em posição de inferioridade, gerada por sua vulnerabilidade (informativa, econômica, técnica, jurídica), em relação ao segurador, no intuito garantir o reequilíbrio contratual das partes e consagrar a justiça contratual nas relações jurídicas securitárias.

Assim, tanto o segurado quanto o segurador, devem verificar a aplicação do princípio da boa-fé-objetiva, durante toda a contratação, desde as tratativas (fase pré-contratual), execução, até após o adimplemento (fase pós-contratual).

Em relação à questão da doença preexistente nos contratos de seguro de vida, imprescindível proceder-se a uma análise do momento de formação do contrato, a partir dos preceitos norteadores do Código de Defesa do Consumidor e do Código Civil de 2002, principalmente, relacionados às informações apresentadas pelos contratantes, acerca do conteúdo contratual, as quais, por parte do segurado, influenciam a mensuração do risco e prêmio, e, por parte do segurador, importam no conhecimento das exclusões e restrições ao direito do segurado, no atendimento do sinistro.

Portanto, tem-se como essencial, o dever de informar do segurador, no que respeita a explicitação ao segurado, de toda informação necessária ao contrato de seguro, bem como seu fornecimento, em consonância com o princípio da transparência. Isso porque, não basta apenas informar, mas, sobretudo, a informação deve ser qualificada, com a finalidade de possibilitar ao segurado a compreensão efetiva dos termos técnicos e das cláusulas limitativas.

Destaca-se, ainda, que as controvérsias envolvendo a doença preexistente, poderiam ser solucionadas, caso as seguradoras tivessem, por praxe a realização de exame médico prévio, sob as condições de saúde dos segurados, para ao firmarem o contrato, terem total conhecimento dos riscos e, conseqüentemente, a mensuração adequada do prêmio, ou mesmo, terem a possibilidade de negarem a contratação do seguro de vida.

É este o entendimento acolhido nos Tribunais, que entendem que a seguradora, que assim não procede assume o risco da atividade econômica desenvolvida, e nesse sentido, tem a obrigação legal de indenizar o segurado em caso de sinistro.

Contudo, conforme destacado, em casos de explícita má-fé do segurado, a sanção prevista em lei deverá ser aplicada, pois o princípio da boa-fé objetiva impõe aos contratantes a observância de preceitos éticos e sociais, na busca do bem comum, refutando assim comportamentos escusos, inclusive, vetados pela legislação pertinente ao contrato de seguro, que consagra a boa-fé como elemento essencial. 
Deste modo, faz-se necessário que ambas as partes - em precípua observância ao princípio da boa-fé objetiva, notadamente, em atenção ao seu dever anexo de informar, bem como aos preceitos basilares norteadores da legislação consumerista (direito à informação, transparência, vulnerabilidade, dentre outros) - disponibilizem, mutuamente, todas as informações necessárias e suficientes à formação do referido contrato, e também, à sua execução, no intuito que este alcance o adimplemento contratual.

\begin{abstract}
This study aims to discuss the legal consequences related the occurrence of pre-existing illness in the contract of life insurance, from the interpretation of that contract, conducted under the focus of the objective good-faith principle, transparency and the right to information, as it figures in the field of Brazilian legal system, according to its features in Consumer Defense Code (1990) and Civil Code (2002). The objective good-faith principle, an essential element of the contract of insurance, restricts private autonomy in the contractual relations, to provide to the parties the possibility of using their liberty in a balanced and cooperative way, according to fundamental principles in the Democratic State of Law.
\end{abstract}

Keywords: contracts, contract of life insurance, objective good-faith, principles, information.

\title{
REFERÊNCIAS
}

AGUIAR JÚNIOR, Ruy Rosado de. A boa-fé na relação de consumo. Revista de Direito do Consumidor, São Paulo, n.14, p. 20-27, abr./jun., 1995.

ALVIM, Pedro. O contrato de seguro. 3. ed. Rio de Janeiro: Forense, 1999.

ALVIM, Pedro. O seguro e o novo Código Civil. Organização e compilação Elizabeth Alvim Bonfioli. Rio de Janeiro: Forense, 2007.

AMARAL, Francisco. Direito civil: introdução. 6. ed. rev. e aum. de acordo com o novo Código Civil. Rio de Janeiro: Renovar, 2006.

BARROSO, Lucas Abreu. O Contrato de seguro e o direito das relações de consumo. Disponível em: <http://www.intelligentiajuridica.com.br/v3/artigo_visualizar.php?id=1042.>. Acesso em: 05. abr. 2007.

BIERWAGEN, Mônica Yoshizato. Princípios e regras de interpretação dos contratos no novo código civil. 2.ed. São Paulo: Saraiva, 2003.

BRASIL. Superior Tribunal de Justiça. Agravo regimental no agravo de instrumento $\mathbf{n}^{\mathbf{0}}$ 818443/RJ (2006/0211788-8). Contrato de seguro de vida. Negativa de pagamento. Doença preexistente. Não-demonstração de má-fé do segurado. Necessidade de prévio exame médico ou prova da efetiva má-fé do segurado. Agravante: Banco do Estado de São Paulo S/A BANESPA. Agravado: Vilma Martins Correa. $3^{\text {a }}$ Turma. Relatora: Min. Nancy Andrighi, Brasília, 01 mar. 2007. Disponível em: 
$<$ http://www.stj.jus.br/SCON/jurisprudencia/doc.jsp?livre=doen\%E7a+preexistente\&\&b=AC OR $\& \mathrm{p}=$ true $\& \mathrm{t}=\& \mathrm{l}=10 \& \mathrm{i}=7>$. Acesso em: 04 abr. 2008.

BRASIL. Superior Tribunal de Justiça. Agravo regimental no agravo de instrumento $\mathbf{n}^{\mathbf{0}}$ 637.921/RJ (2004/0153583-0). Contrato de seguro de vida. Negativa de pagamento. Doença preexistente. Boa-fé. Agravante: Citibank Corretora de Seguros S/A. Agravado: Yberê De Freitas Ximenes. $4^{a}$ Turma. Relator: Min. Monteiro de Barros, Brasília, 07 fev. 2006.

Disponível em:

<http://www.stj.jus.br/SCON/jurisprudencia/doc.jsp?livre=doen $\% \mathrm{E} 7 \mathrm{a}+$ preexistente $\& \& \mathrm{~b}=\mathrm{AC}$ OR\&p=true \& $\mathrm{t}=\& \mathrm{l}=10 \& \mathrm{i}=21>$. Acesso em: 04 abr. 2008.

BRASIL. Supremo Tribunal Federal. Tribunal Pleno. Ação Direta de

Inconstitucionalidade n⿳2591-1/DF. Rel. Min. Carlos Velloso. 07 de Junho de 2006.

Disponível em:

$<$ http://www.stf.gov.br/globais/paginarpdf/default.asp?id=266854\&desc=ADI-

2591\&tipo=AC\&docTP $=$ AC $>$. Acesso em 10 ago. 2007

BENJAMIN, Antônio Herman V.; MARQUES, Claudia Lima; BESSA, Leonardo Roscoe. Manual de direito do consumidor. São Paulo: Revista dos Tribunais, 2007.

CARVALHO, José Carlos Maldonado de. Direito do consumidor: fundamentos doutrinários e visão jurisprudencial. 2.ed., Rio de Janeiro: Lumen Juris, 2007.

CAVALIERI FILHO, Sergio. Os Contratos de Transporte de Pessoas e de Seguro no Novo Código Civil. Revista da EMERJ, Rio de Janeiro: Escola da Magistratura do Estado do Rio de Janeiro. Anais dos Seminários EMERJ debate o Novo Código Civil. Parte I, p.206218, fev./jun. 2002.

CAVALIERI FILHO, Sergio. Programa de responsabilidade civil. 7. ed. rev., ampl. São Paulo: Atlas, 2007, p.416.

CECCONELLO, Fernanda Ferrarini G. C. Seguro de vida: morte por doença preexistente. Revista Síntese de Direito Civil e Processual Civil, Porto Alegre, v.2, n.9, p. 15-17, jan./fev.2001.

CORDEIRO, António Manuel da Rocha e Menezes. Da boa-fé no direito civil. Coimbra: Almedina, 2007.

CORDEIRO, António Manuel da Rocha e Menezes. Tratado de direito civil português: volume 1: parte geral, tomo 1: introdução doutrina geral negócio jurídico. 3. ed. aumentada e inteiramente revista. Coimbra: Almedina, 2005.

COUTO E SILVA, Clóvis do. A obrigação como processo. São Paulo: José Bushatsky, 1976.

DELGADO, José Augusto. Comentários ao Novo Código Civil. Rio de Janeiro: Forense, v. XI, t.I, 2004.

DINIZ, Maria Helena. Curso de direito civil brasileiro: Teoria das obrigações contratuais e extracontratuais. 19. ed. São Paulo: Saraiva, 2003, v.3. 
DINIZ, Maria Helena. Tratado teórico e prático dos contratos. 6. ed., rev., ampl. e atual. São Paulo: Saraiva, 2006, v.4.

FARIAS, Cristiano Chaves de; ROSENVALD, Nelson. Direito das obrigações. Rio de Janeiro: Lumen Juris, 2006.

FABIAN, Christoph. O dever de informar no direito civil. São Paulo: Revista dos Tribunais, 2002.

FIUZA, César. Direito Civil: curso completo. 9. ed. rev., atual. e ampl. Belo Horizonte: Del Rey, 2006.

FIUZA, César; ROBERTO, Giordano Bruno Soares. Contratos de adesão: de acordo com o novo Código Civil. Belo Horizonte: Mandamentos, 2002.

GARCIA, Leonardo de Medeiros. Direito do consumidor. 3.ed., Rio de Janeiro: Impetus, 2007.

GOMES, Orlando. Contratos. 26 ed. Rio de Janeiro: Forense, 2007.

GOMES, Rogério Zuel. Teoria contratual contemporânea: função social do contrato e boa-fé. Rio de Janeiro: Forense, 2004.

GRINOVER, Ada Pellegrini et al. Código brasileiro de defesa do consumidor: comentado pelos autores do anteprojeto. 9. ed. rev., ampl. e atual. conforme o novo Código Civil. Rio de Janeiro: Forense Universitária, 2007.

GUERREIRO, Marcelo da Fonseca. Seguros privados: doutrina, legislação e jurisprudência. 2.ed., Rio de Janeiro: Forense Universitária, 2004.

HIRONAKA, Giselda Maria Fernandes Novaes. Tendências do Direito Civil no Século XXI. In: FIUZA, César; SÁ, Maria de Fátima Freire de; NAVES, Bruno Torquato de Oliveira (Coords.). Direito Civil: atualidades. Belo Horizonte: Del Rey, 2003, p.93-114.

KRIGER FILHO, Domingos Afonso. Contrato de seguro no direito brasileiro. Niterói: Labor Juris, 2000.

LÔBO, Paulo Luiz Netto. Comentários ao artigo 765 do Código Civil. In: PEREIRA, Rodrigo da Cunha et al. (Coords.). Código Civil anotado. Porto Alegre: Síntese, 2004.

LÔBO, Paulo Luiz Netto. Princípios sociais dos contratos no Código de Defesa do Consumidor e no novo Código Civil. Revista de Direito do Consumidor, São Paulo, v.11, n.42, p.187-195, abr./jun. 2002.

LÔBO, Paulo Luiz Netto. Teoria geral das obrigações. São Paulo: Saraiva, 2005.

LÔBO, Paulo Luiz Netto. A informação como direito fundamental do consumidor. Jus Navigandi, Teresina, ano 5, n. 51, out. 2001. Disponível em:

<http://jus2.uol.com.br/doutrina/texto.asp?id=2216>. Acesso em: 16 nov. 2007

MARENSI, Voltaire Giavarina. O seguro no direito brasileiro. 8.ed., São Paulo: IOB Thomson, 2007. 
MARQUES, Claudia Lima. Contratos no código de defesa do consumidor: o novo regime das relações contratuais. 5. ed. rev., atual. e ampl. São Paulo: Revista dos Tribunais, 2006.

MARTINS, João Marcos Brito. O contrato de seguro: comentado conforme as disposições do Código Civil, Lei ${ }^{\circ} 10.406$, de 10 de janeiro de 2002. 2.ed., Rio de Janeiro: Forense Universitária, 2005.

MARTINS-COSTA, Judith. A boa-fé no direito privado: sistema e tópica no processo obrigacional. São Paulo: Revista dos Tribunais, 2000.

MARTINS-COSTA, Judith. Mercado e solidariedade social entre cosmos e táxis: A boa-fé nas relações de consumo. In: MARTINS-COSTA, Judith (Org.). A reconstrução do direito privado: reflexos dos princípios, diretrizes e direitos fundamentais constitucionais no direito privado. São Paulo: Revista dos Tribunais, 2002, p. 611-661.

MATOS, Robson Pedron; MOLINA, Fabiana Ricardo. O contrato de seguro e o Código de Defesa do consumidor. São Paulo: Quartier Latin, 2006.

MELLO, Heloísa Carpena Vieira de. A boa-fé como parâmetro da abusividade no direito contratual. In: TEPEDINO, Gustavo (Coord.). Problemas de direito civil-constitucional. Rio de Janeiro: Renovar, 2001, p.307-324.

MINAS GERAIS. Tribunal de Justiça. Embargos Infringentes $n^{\circ}$ 1.0395.03.004716-5/003 em Apelação Cível no 1.0395.03.004716-5/001. Ação de cobrança de seguro de vida. Doença preexistente. Não comprovada a má-fé do segurado. Embargante: Rosa Maura de Souza Oliveira. Apelado: Caixa Seguradora S/A. 13 ${ }^{a}$ Câmara Cível. Relator: Des. Adilson Lamounier. Belo Horizonte, 06 mar. 2008. Disponível em:

<http://www.tjmg.gov.br/juridico/jt_/inteiro_teor.jsp?tipoTribunal=1\&comrCodigo=395\&ano $=3 \&$ txt_processo $=4716 \&$ complemento $=3 \&$ sequencial $=0 \&$ palavrasConsulta $=$ doença $\% 20$ pree xistente $\&$ todas $=\&$ expressao $=\&$ qualquer $=\&$ sem $=\&$ radical $=>$.Acesso em: 04 abr. 2008.

MINAS GERAIS. Tribunal de Justiça. Apelação Cível N 1.0024.05.873032-6/001.

Cobrança de seguro de vida. Doença preexistente. Não comprovada a má-fé do segurado. CDC. Apelante: Itaú Prev. Seguradora S/A. Apelado: Luis Inácio Sampaio. $17^{a}$ Câmara Cível. Relator: Des. Luciano Pinto. Belo Horizonte, 14 nov. 2007. Disponível em:

<http://www.tjmg.gov.br/juridico/jt_/inteiro_teor.jsp?tipoTribunal=1\&comrCodigo=24\&ano= $5 \&$ txt_processo $=873032 \&$ complemento $=1 \&$ sequencial $=0 \&$ palavrasConsulta $=$ doença $\% 20$ pre existente $\&$ todas $=\&$ expressao $=\&$ qualquer $=\&$ sem $=\&$ radical $=>$.Acesso em: 04 abr. 2008.

NALIN, Paulo. Do contrato: conceito pós-moderno em busca de sua formulação na perspectiva civil-constitucional. 2.ed., Curitiba: Juruá, 2006.

NEGREIROS, Teresa. Teoria do contrato: novos paradigmas. 2.ed., Rio de Janeiro: Renovar, 2006.

NERY JÚNIOR, Nelson. Contrato de Seguro de Vida em Grupo e o Código de Defesa do Consumidor. Revista Direito Privado, São Paulo: Revista dos Tribunais, v.3, n.10, p.165210, abr./jun., 2002.

NERY JÚNIOR, Nelson; NERY, Rosa Maria Andrade. Código civil comentado. 4. ed. rev., atual. e ampl. São Paulo: Revista dos Tribunais, 2006. 
NORONHA, Fernando. O direito dos contratos e seus princípios fundamentais: autonomia privada, boa-fé, justiça contratual. São Paulo: Saraiva, 1994.

NORONHA, Fernando. Direito das obrigações: volume 1: fundamentos do direito das obrigações, introdução à responsabilidade civil. 2. ed. rev. e atual. São Paulo: Saraiva, 2007.

NOVAIS, Alinne Arquette Leite. Os novos paradigmas da teoria contratual: o princípio da boa-fé objetiva e o princípio da tutela do hipossuficiente. In: TEPEDINO, Gustavo (Coord.). Problemas de Direito Civil-Constitucional, Rio de Janeiro: Renovar, 2001, p.17-54.

RIBEIRO, Joaquim de Sousa. O Imperativo de Transparência no Direito Europeu dos Contratos. In: FIUZA, César; SÁ, Maria de Fátima Freire de; NAVES, Bruno Torquato de Oliveira (Coords.). Direito civil: atualidades. Belo Horizonte: Del Rey, 2003, p.131-157.

RIZZARDO, Arnaldo. Código de Defesa do Consumidor nos Contratos de Seguro-Saúde e Previdência Privada. Ajuris, v.22, n.64, p.78-102, jul/1995.

ROSENVALD, Nelson. Dignidade humana e boa-fé no Código Civil. São Paulo: Saraiva, 2005.

ROSENVALD, Nelson. A função social do contrato. In: HIRONAKA, Giselda Maria Fernandes Novaes; TARTUCE, Flávio (Coords.). Direito Contratual: temas atuais. São Paulo: Método, 2007, p.81-111.

SANTA CATARINA. Tribunal de Justiça. Apelação civil no 2004.021286-0. Contrato de Seguro de vida. Negativa de pagamento. Doença Preexistente. Apelante: AGF Brasil Seguros S/A. Apelada: Sônia Rosa Andrade. $2^{\text {a }}$ Câmara de Direito Civel. Relator: Des. Jorge Henrique Schaefer Martins. Florianópolis, 02 mar. 2006. Disponível em:

<http://tjsc6.tj.sc.gov.br/jurisprudencia/PesquisaAvancada.do>. Acesso em: 04 abr. 2008.

SANTOS, Ricardo Bechara dos. Direito de seguro no novo Código Civil e legislação própria. Rio de Janeiro: Forense, 2006.

SCHIER, Flora Margarida Clock. A boa-fé como pressuposto fundamental do dever de informar. Curitiba: Juruá, 2006.

SETTE, André Luiz Menezes Azevedo. Direito dos contratos: seus princípios fundamentais sob a ótica do Código Civil de 2002. Belo Horizonte: Mandamentos, 2003.

SHIH, Frank Larrúbia. Temas relevantes de direito securitário. Rio de janeiro: Lumen Juris, 2003.

SILVA, Jorge Cesa Ferreira da. A boa-fé e a violação positiva do contrato. Rio de Janeiro: Renovar, 2002.

TARTUCE, Flávio. Função social dos contratos: do Código de Defesa do Consumidor ao Código Civil de 2002. 2.ed., São Paulo: Método, 2007.

TAVARES, Fernando Horta. Seguro. Virtuajus. Revista Eletrônica da Faculdade Mineira de Direito. Ano 3, n. 1, julho de 2004. Disponível em:

<http://www.fmd.pucminas.br/Virtuajus/1_2004/SEGURO.pdf>. Acesso em: 21 jul. 2006.

Revista da Faculdade Mineira de Direito, v.12, n. 23, jan./jun. 2011 - ISSN 1808-9429. 
TEPEDINO, Gustavo. Normas Constitucionais e Direito Civil. Revista da Faculdade de Direito de Campos. Ano IV, No 4 e Ano V, No 5 - 2003-2004, p. 170-171. Disponível em: <http://www.fdc.br/Arquivos/Mestrado/Revistas/Revista04e05/Docente/10.pdf > . Acesso em: 22 jul. 2006.

TEPEDINO, Gustavo; SCHREIBER, Anderson. A boa-fé objetiva no Código de Defesa do Consumidor e no Código Civil de 2002. In: PASQUALOTTO, Adalberto; PFEIFFER, Roberto Augusto Castellanos (Coords.). Código de Defesa do Consumidor e o Código Civil de 2002: convergências e assimetrias. São Paulo: Revista dos Tribunais, 2005, p.216-231.

THEODORO JÚNIOR, Humberto. Direitos do consumidor: a busca de um ponto de equilíbrio entre garantias do Código de Defesa do Consumidor e os princípios gerais do Direito Civil e do Direito Processual Civil. 5. ed., Rio de Janeiro: Forense, 2008.

THEODORO JÚNIOR, Humberto. O contrato de seguro e a regulação do sinistro. Revista Síntese de Direito Civil e Processual Civil, Porto Alegre, v.5, n.30, p. 5-23, jul./ago. 2004.

TOMASETTI JUNIOR, Alcides. O objetivo de transparência e o regime jurídico dos deveres e riscos de informação nas declarações negociais para consumo. Revista de Direito do Consumidor, São Paulo, n.4, p.52-90, 1992.

TZIRULNIK, Ernesto. Estudos de direito do seguro: regulação de sinistro (ensaio jurídico). 3.ed. rev. São Paulo: Max Limonad, 2001.

TZIRULNIK, Ernesto; CAVALCANTI, Flávio de Queiroz B.; PIMENTEL, Ayrton. O contrato de seguro: novo código civil brasileiro. São Paulo: Instituto Brasileiro de Direito do Seguro, 2002.

ZULIANI, Ênio Santarelli. Código de Defesa do Consumidor e a Jurisprudência do Tribunal de Justiça do Estado de São Paulo. Revista Síntese de Direito Civil e Processual Civil, Porto Alegre, v.5, n.29, p.37-58, maio/jun. 2004. 